\title{
STUDI MUTU BATA BETON (PAVING BLOCK) YANG MENGGUNAKAN ABU PUING UBIN KERAMIK SEBAGAI BAHAN PENGGANTI SEBAGIAN SEMEN \\ Ir.Erna Septiandini,MT dan Ariana Sofiah
}

\begin{abstract}
Abstrak
Penelitian ini bertujuan untuk mengetahui apakah mutu bata beton (paving block) dengan abu puing ubin keramik sebagai bahan pengganti sebagian semen dengan persentase $15 \%, 20 \%, 25 \%$, dan $30 \%$ dari berat semen dapat memenuhi mutu bata beton (paving block) standar nasional (SNI 03-0691-1996).

Benda uji paving block menggunakan komposisi campuran 1 (semen+abu puong keramik) : 4 pasir berukuran $20 \mathrm{~cm} \times 10 \mathrm{~cm} \times 6 \mathrm{~cm}$. Pengujian yang dilakukan terhadap paving block adalah kuat tekan, daya serap air dan ketahanan aus berdasarkan SNI 03-0691-1996.

Dari hasil pengujian hipotesis dengan uji $t$ didapat bahwa penggunaan abu puing keramik sebesar $15 \%$ dari berat semen menghasilkan nilai kuat tekan rata-rata 23,336 $\mathrm{MPa}$, lebih tinggi dari kuat tekan bata beton mutu $B$ standar SNI 03-0691-1996 (20 MPa), sedangkan penggunaan abu puing keramik sebesar 20\% dan 25\% menghasilkan kuat tekan di atas kuat tekan mutu C standar SNI (15 MPa) dan penggunaan abu puing keramik sebesar $30 \%$ dari berat semen masih termasuk dalam kuat tekan standar mutu C SNI. Hasil uji untuk nilai rata-rata penyerapan air lebih tinggi (belum memenuhi persyaratan) dari standar SNI 03-0691-1996 mutu D(10\%). Nilai rata-rata ketahanan aus paving block semakin tinggi jika persentase penggunaan abu puing keramik semakin besar. Hanya penggunaan sebesar $15 \%$ dari berat semen yang nilai rata-rata ketahanan ausnya lebih rendah dari nilai rata-rata ketahanan aus standar SNI mutu D $(0,219 \mathrm{~mm} /$ menit $)$.

Kata Kunci: bata beton, puing ubin keramik, kuat tekan, daya serap, ketahanan aus.
\end{abstract}

Studi Mutu Bata Beton (Paving Block) Yang Menggunakan Abu Puing Ubin Keramik Sebagai Bahan Pengganti Sebagian Semen (Ir.Erna Septiandini, MT., Dosen Jurusan Teknik Sipil FT- UNJ.) 


\section{Pendahuluan}

Bata Beton (paving block) merupakan salah satu bahan bangunan yang digunakan untuk pembangunan jalan, pelataran parkir, trotoar (untuk pejalan kaki), taman dan pengguna lain.

Dengan semakin meningkatnya penggunaan bata beton (paving block) sebagai material pembangunan jalan, kebutuhan akan bahan-bahan pembentuknya semakin meningkat. Bahan pengikat hidrolis yang digunakan untuk pembuatan bata beton adalah semen portland. Semen portland sebagai bahan pengikat dalam pembuatan bata beton merupakan bahan bangunan yang juga sangat sering digunakan untuk pembangunan gedung ataupun jalan raya. Oleh karena itu untuk mencegah langkanya bahan bangunan tersebut maka perlu dicari alternatif bahan penggantinya terutama semen, karena harga semen setiap waktunya akan terus melonjak naik.

Pada pabrik-pabrik pengolahan keramik lantai banyak terdapat limbah yang menumpuk dan tak dapat digunakan lagi. Ada dua macam limbah dari pengolahan keramik lantai yang tidak dapat dimanfaatkan kembali, yaitu limbah cair, berupa sisa pengglasuran permukaan keramik, dan limbah padat, berupa puing-puing ubin keramik yang gagal atau cacat produksi. Limbah padat industri keramik merupakan ubin keramik cacat produksi disebabkan pecah di dalam tungku, cacat glasur dan cacat penampakan (bentuk dan warna). Limbah padat industri keramik (puing ubin keramik) lambat laun akan menumpuk, tapi untuk hal tersebut ada baiknya apabila limbah padat industri keramik tersebut dapat digunakan kembali. Puing ubin keramik merupakan pecahan-pecahan/potongan-potongan ubin keramik dengan bahan baku antara lain: kaolin, lempung, feldspar dan silika. Dengan demikian puing ubin keramik yang telah dihaluskan hingga menyerupai kehalusan semen diduga akan dapat menggantikan sebagian dari semen portland untuk pembuatan bata beton (paving block)

\section{Identifikasi Masalah}

Berdasarkan latar belakang masalah, maka dapat diidentifikasi beberapa masalah sebagai berikut: Apakah abu puing ubin keramik dapat menggantikan sebagian semen? Apakah terdapat perbedaan mutu antara bata beton yang menggunakan bahan pengganti abu puing ubin keramik dengan bata beton 
standar nasional? Berapa besar persentase nominal abu puing ubin keramik yang dipergunakan agar didapat mutu bata beton yang sesuai dengan kuat tekan bata beton standar nasional? Apakah bata beton yang menggunakan bahan pengganti abu puing ubin keramik dapat memenuhi persyaratan mutu bata beton standar nasional? Apakah mutu bata beton yang menggunakan bahan pengganti abu puing ubin keramik lebih tinggi daripada mutu beton standar nasional?

\section{Pembatasan Masalah}

Dari identifikasi beberapa masalah tersebut maka batasan permasalahan yang akan diteliti adalah mengenai mutu bata beton (paving block) dengan abu puing ubin keramik sebagai bahan pengganti sebagian semen dengan persentase $15 \%, 20 \%, 25 \%$ dan $30 \%$ dari berat semen.

\section{Perumusan Masalah}

Berdasarkan pada pembatasan masalah di atas maka dapat dirumuskan permasalahan sebagai berikut : Apakah mutu bata beton (paving block) yang menggunakan abu puing ubin keramik sebagai bahan pengganti sebagian semen dengan persentase $15 \%, 20 \%, 25 \%$ dan $30 \%$ dari berat semen memenuhi persyaratan Standar Nasional Indonesia SNI 03-0691-1996?

\section{Studi Pustaka}

1. Bata beton (paving block)

Bata beton (paving block) adalah suatu komposisi bahan bangunan yang dibuat dari campuran semen portlnd atau bahan perekat hidrolis sejenisnya, air dan agregat dengan atau tanpa bahan tambahan lainnya yang tidak mengurangi mutu bata beton itu

Mutu Bata beton (paving block) menurut SNI 03-0691-1996 harus memenuhi persayaratan sebagai berikut:

a. Sifat tampak. Bata Beton harus mempunyai permukaan yang rata tidak terdapat retak-retak dan cacat, bagian sudut dan rusuknya tidak mudah dirapihkan dengan kekuatan jari tangan.

b. Ukuran dan bentuk. Bata Beton harus mempunyai ukuran tebal nominal minimum $60 \mathrm{~mm}$ dengan toleransi $\pm 80 \%$. Ukuran bata beton (paving block) yang berbentuk segi-4 menurut SK-SNI-T-04-1990-F adalah : panjang 20

Studi Mutu Bata Beton (Paving Block) Yang Menggunakan Abu Puing Ubin Keramik Sebagai Bahan Pengganti Sebagian Semen (Ir.Erna Septiandini, MT., Dosen Jurusan Teknik Sipil FT- UNJ.) 
$\mathrm{cm}$, lebar $10 \mathrm{~cm}$ dan tebal $6 \mathrm{~cm}, 8 \mathrm{~cm}, 10 \mathrm{~cm}$. Ketebalan $6 \mathrm{~cm}$, dipergunakan untuk trotoar, pertamanan, tempat parkir dan garasi. Ketebalan $8 \mathrm{~cm}$, dipergunakan untuk jalan lingkungan dan terminal bus. Ketebalan $10 \mathrm{~cm}$, dipergunakan untuk jalan (angkutan berat).

c. Sifat fisik. Persyaratan sifat fisika dapat dilihat pada tabel di bawah ini: Tabel 1. Sifat-sifat Fisika

\begin{tabular}{|c|c|c|c|c|c|}
\hline Mutu & \multicolumn{2}{|c|}{ Kuat Tekan (MPa) } & \multicolumn{2}{c|}{$\begin{array}{c}\text { Ketahanan Aus } \\
\text { (mm/menit) }\end{array}$} & $\begin{array}{c}\text { Penyerapan Air } \\
\text { Rata-rata maks }\end{array}$ \\
\cline { 2 - 6 } & $\begin{array}{c}\text { Rata- } \\
\text { rata }\end{array}$ & Min & Rata-rata & Maks & $\%$ \\
\hline A & 40 & 35 & 0,090 & 0,103 & 3 \\
B & 20 & 17,0 & 0,130 & 0,149 & 6 \\
C & 15 & 12,5 & 0,160 & 0,184 & 8 \\
D & 10 & 8,5 & 0,219 & 0,251 & 10 \\
\hline
\end{tabular}

Sumber SNI 03-0691-1996

\section{Abu Puing Ubin Keramik}

Abu puing ubin keramik merupakan abu (butiran halus) yang dihasilkan dari penggilingan pecahan-pecahan/potongan-potongan ubin keramik yang cacat produksi, lalu dihaluskan hingga ukuran butirannya relatif sama dengan butiran semen. Bahan kimia yang terkandung dalam abu puing ubin keramik adalah: $\mathrm{CaO}, \mathrm{SiO}_{2}, \mathrm{Al}_{2} \mathrm{O}_{3}, \mathrm{Fe}_{2} \mathrm{O}_{3}, \mathrm{MgO}$. Secara fisik butiran abu puing ubin keramik berwarna coklat muda dan tidak berbau

\section{Metodologi Penelitian}

1. Tujuan penelitian

Penelitian ini bertujuan untuk mengetahui apakah mutu Apakah mutu bata beton (paving block) yang menggunakan abu puing ubin keramik sebagai bahan pengganti sebagian semen dengan persentase 15\%,20\%,25\% dan 30\% dari berat semen memenuhi persyaratan Standar Nasional Indonesia SNI 030691-1996.

2. Metode Penelitian

Metode yang digunakan adalah metode eksperimen di laboratorium dengan benda uji bata beton dengan abu puing ubin keramik sebagai bahan pengganti sebagian semen Portland. Variabel - variabel penelitian ini yaitu : 
a. Variabel bebas yaitu penggunaan abu puing ubin keramik sebagai bahan pengganti sebagian semen.

b. Varibel terikat yaitu mutu bata beton (paving block).

3. Prosedur kerja penelitian:

A. Tahap Pemeriksaan Bahan

Pemeriksaan bahan dilakukan terhadap masing-masing bahan dasar agar diketahui sifat-sifat bahan tersebut seperti di bawah ini :

a. Semen

Pada penelitian ini digunakan semen tipe I cap Tiga Roda. Untuk semen tidak dilakukan pengujian karena sudah memenuhi syarat semen portland.

b. Agregat Halus (pasir)

(1) Pemeriksaan zat organik dalam pasir. Prosedur pengujian ini sesuai dengan SNI 03-2816-1990.

(2) Pengujian indeks kekerasan butiran pasir. Pengujian indeks kekerasan pasir sesuai dengan SNI 03-1756-1990.

(3) Pengujian kadar Lumpur. Pengujian kadar lumpur pasir sesuai dengan SNI 03-1754-1990.

(4) Pengujian gradasi pasir. Prosedur penelitian ini sesuai dengan SNI 03-1968-1990.

(5) Pengujian analisis specifik gravity dan penyerapan air pasir.

Pengujian ini dilakukan sesuai dengan SNI 03-1970-1990.

c. Abu Puing Keramik

Puing-puing keramik (limbah padat industri ubin keramik) yang masih berupa potongan-potongan atau pecahan-pecahan ubin keramik dihaluskan dengan proses penggilingan mempergunakan ballmill . Setelah dilakukan penggilingan abu puing ubin keramik kemudian diayak dengan ayakan no.200. Proses penghalusan abu puing ubin keramik dapat dilihat pada gambar 1. di bawah ini: 


\begin{tabular}{|c|c|c|}
\hline $\begin{array}{l}\text { Pengambilan puing } \\
\text { ubin keramik (limbah } \\
\text { padat) }\end{array}$ & $\begin{array}{l}\text { Penggilingan dengan } \\
\text { ballmill }\end{array}$ & $\begin{array}{l}\text { Pengayakan } \\
\text { dengan ayakan } \\
\text { no. } 200\end{array}$ \\
\hline
\end{tabular}

Gambar 1

d. Air

Air yang digunakan dalam penelitian ini adalah air PAM, maka tidak dilakukan pemeriksaan karena telah memenuhi standar persyaratan.

B. Tahap Pembuatan Benda Uji

a. Bata beton (paving block)

Benda uji dibuat berukuran $20 \mathrm{~cm} \times 10 \mathrm{~cm} \times 6 \mathrm{~cm}$ dengan menggunakan mesin press. Perbandingan campuran semen dan pasir pada pembuatan bata beton ini digunakan perbandingan berat, yaitu 1 (semen+abu puing keramik): 4 pasir dengan faktor air semen 0,45. Abu puing ubin keramik digunakan sebagai bahan pengganti sebagian semen pada variasi yang berbeda yaitu 15\%, 20\% dan 25\%, 30\%. Setelah dicetak dan dibiarkan mengering benda uji direndam dalam air selama 28 hari.

C. Tahap Pengujian Benda Uji

Pengujian bata beton dilakukan sesuai dengan SNI 03-0691-1996. Pengujian yang dilakukan adalah pengujian kuat tekan, daya serap air dan ketahanan aus dan dilakukan setelah bata beton berumur 28 hari. Pemeriksaan yang dilakukan sebelum pengujian adalah dengan memeriksa ukuran dan penimbangan berat

\section{Rancangan Penelitian}

Adapun perlakuan yang akan diberikan untuk kelompok bata beton adalah sebagai berikut : 
Tabel 2. Perlakuan yang diberikan untuk kelompok bata beton (paving block)

\begin{tabular}{|c|c|}
\hline Kelompok & Komposisi campuran \\
\hline$A_{1}$ & $(0,15$ abu puing ubin keramik $+0,85$ semen $): 4$ pasir \\
$A_{2}$ & $(0,20$ abu puing ubin keramik $+0,80$ semen $): 4$ pasir \\
$A_{3}$ & $(0,25$ abu puing ubin keramik $+0,75$ semen $): 4$ pasir \\
$A_{4}$ & $(0,30$ abu puing ubin keramik+0,70 semen $): 4$ pasir \\
\hline
\end{tabular}

5. Teknik Pengambilan Populasi dan Sampel

a. Populasi

Populasi dalam penelitian ini adalah bata beton dengan abu puing ubin keramik sebagai bahan pengganti sebagian semen dengan persentase $15 \%, 20 \%, 25 \%$ dan $30 \%$ dari berat semen.

a. Sampel

Sampel yang digunakan pada penelitian ini adalah bata beton dengan abu puing ubin keramik sebagai bahan pengganti sebagian semen dari 4 perlakuan dengan jumlah benda uji dari masing-masing perlakuan sebanyak 20 buah yang jumlah pengambilan sampel dilakukan secara acak sebanyak 10 buah benda uji untuk pengujian kuat tekan dan 5 buah benda uji pula untuk pengujian penyerapan air dan ketahanan aus.

6. Instrumen

Instrumen yang digunakan untuk penelitian adalah alat pencetak bata beton, alat penggiling/penghalus batu, seperangkat alat ukur (panjang, berat, volume dan waktu), seperangkat alat uji untuk agregat halus, seperangkat alat uji untuk kuat tekan bata beton dan blanko pengisian data, seperangkat alat uji untuk ketahanan aus, seperangkat alat uji untuk daya serap.

\section{Teknik Analisis Data}

Pada penelitian ini sebelum dilakukan pengujian hipotesis, terlebih dahulu data perlu diuji normalitas dan homogenitas. Persyaratan analisis data untuk menguji normalitas data menggunakan uji Liliefors, sedangkan persyaratan analisis data untuk menguji homogenitas data menggunakan uji Barlett. Untuk pengujian hipotesis digunakan pengujian uji t.

8. Hipotesis Statistik

Hipotesis statistik dalam penelitian ini yaitu :

Studi Mutu Bata Beton (Paving Block) Yang Menggunakan Abu Puing Ubin Keramik Sebagai Bahan Pengganti Sebagian Semen (Ir.Erna Septiandini, MT., Dosen Jurusan Teknik Sipil FT- UNJ.) 
1. Hipotesis pertama $: \mathrm{H}_{0}: \mu_{\mathrm{A}}=\mu_{\mathrm{S}}$, artinya : mutu bata beton (paving block) yang menggunakan abu puing ubin keramik dengan mutu bata beton (paving block) Standar Nasional Indonesia adalah sama.

2. Hipotesis kedua: $\mathrm{H}_{1}: \mu_{\mathrm{A}}>\mu_{\mathrm{S}}$, artinya : mutu bata beton (paving block) untuk yang menggunakan abu puing ubin keramik mempunyai nilai yang lebih baik daripada mutu bata beton (paving block) Standar Nasional Indonesia.

\section{Hasil Penelitian Dan Pembahasan}

1. Hasil Pengujian bahan-bahan pembentuk beton

a. Pasir

Tabel 3. Hasil Pengujian Pasir

\begin{tabular}{|l|c|}
\hline \multicolumn{1}{|c|}{ Jenis Pengujian } & Hasil Pengujian \\
\hline Modulus kehalusan & 2,74 \\
& zone 2 \\
Berat Jenis kering & 1,88 \\
Berat Jenis SSD & 2,20 \\
Apparent Specifik Gravity & 1,44 \\
Penyerapan (\%) & 16,34 \\
Kadar Lumpur (\%) & 11,45 \\
Indeks kekerasan & 3,2 \\
Kandungan Zat Organik & Kuning muda \\
\hline
\end{tabular}

b. Abu Puing Ubin Keramik

Tabel 4. Sifat Kimia Abu Puing Keramik

\begin{tabular}{|c|c|}
\hline Parameter Analisis & Persentase \\
\hline $\mathrm{CaO}$ & 5,95 \\
$\mathrm{SiO}$ & 58,39 \\
$\mathrm{Al}_{2} \mathrm{O}_{3}$ & 13,56 \\
$\mathrm{Fe}_{2} \mathrm{O}_{3}$ & 34,4 \\
$\mathrm{MgO}$ & 1,11 \\
\hline
\end{tabular}

Tabel 5. Sifat Fisik Abu Puing Keramik

\begin{tabular}{|c|c|}
\hline Pemeriksaan & Hasil Pemeriksaan \\
\hline Warna & Coklat Muda \\
Bau & Tidak Berbau \\
Kadar Air & $<35 \%$ \\
\hline
\end{tabular}

MENARA, JURNAL TEKNIK SIPIL VOL. I, NO. 2 JULI 2006: 200-212 
2. Hasil Pengujian Ukuran Bata Beton

Tabel 6. Hasil Pengujian Ukuran Bata Beton

\begin{tabular}{|c|c|c|c|c|}
\hline \multirow{2}{*}{ Kelompok } & \multicolumn{4}{|c|}{ Ukuran Rata-rata Bata Beton } \\
\cline { 2 - 5 } & $\begin{array}{l}\text { Panjang } \\
(\mathrm{cm})\end{array}$ & $\begin{array}{l}\text { Lebar } \\
(\mathrm{cm})\end{array}$ & $\begin{array}{l}\text { Tebal } \\
(\mathrm{cm})\end{array}$ & $\begin{array}{c}\text { Berat } \\
(\mathrm{kg})\end{array}$ \\
\hline $\mathrm{A}_{1}$ & 20,21 & 10,31 & 6,29 & 2,748 \\
\hline $\mathrm{A}_{2}$ & 20,11 & 10,26 & 6,73 & 2.803 \\
\hline $\mathrm{A}_{3}$ & 20,03 & 10,34 & 6,56 & 2,658 \\
\hline $\mathrm{A}_{4}$ & 20,05 & 10,44 & 5,68 & 2,733 \\
\hline
\end{tabular}

3. Hasil Pengujian Kuat Tekan Bata beton

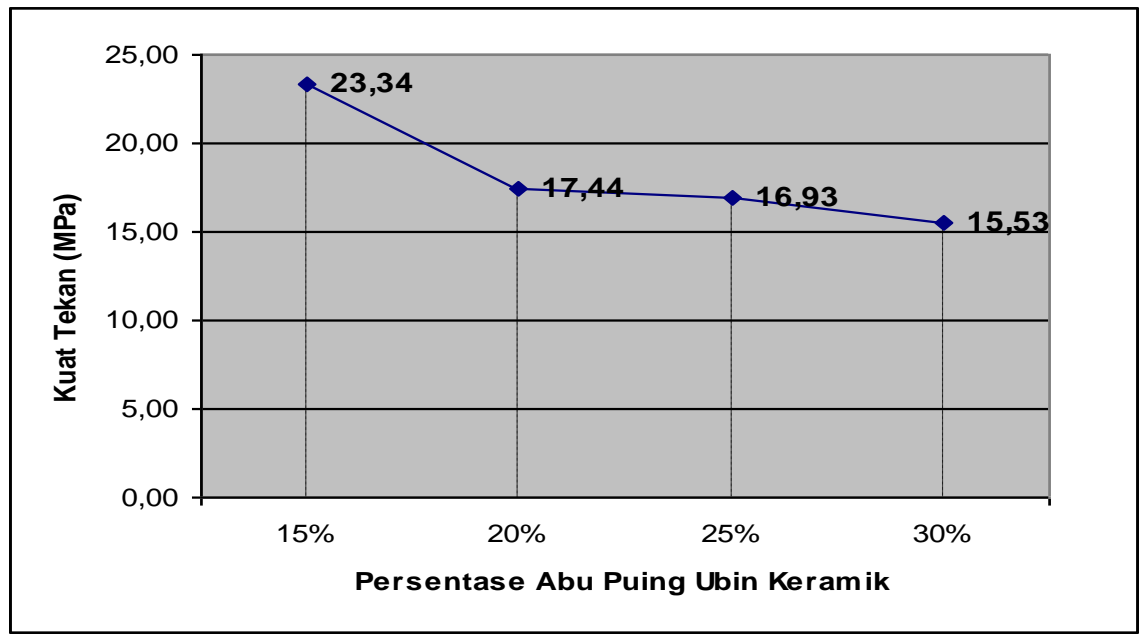

4. Hasil Pengujian Penyerapan Air Bata Beton

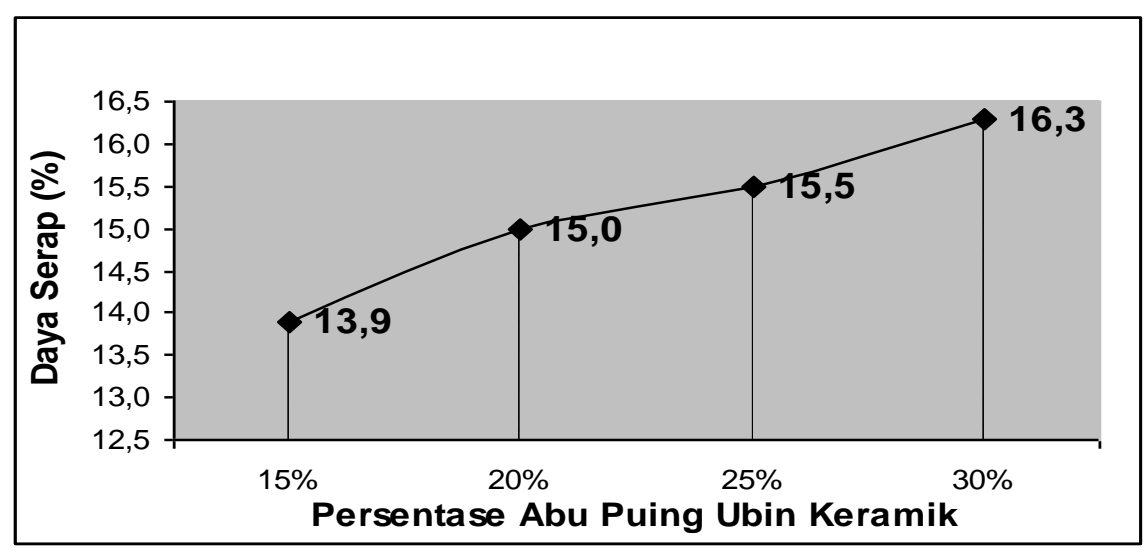

Studi Mutu Bata Beton (Paving Block) Yang Menggunakan Abu Puing Ubin Keramik Sebagai Bahan Pengganti Sebagian Semen (Ir.Erna Septiandini, MT., Dosen Jurusan Teknik Sipil FT- UNJ.) 
5. Hasil Pengujian Ketahanan Aus Bata Beton

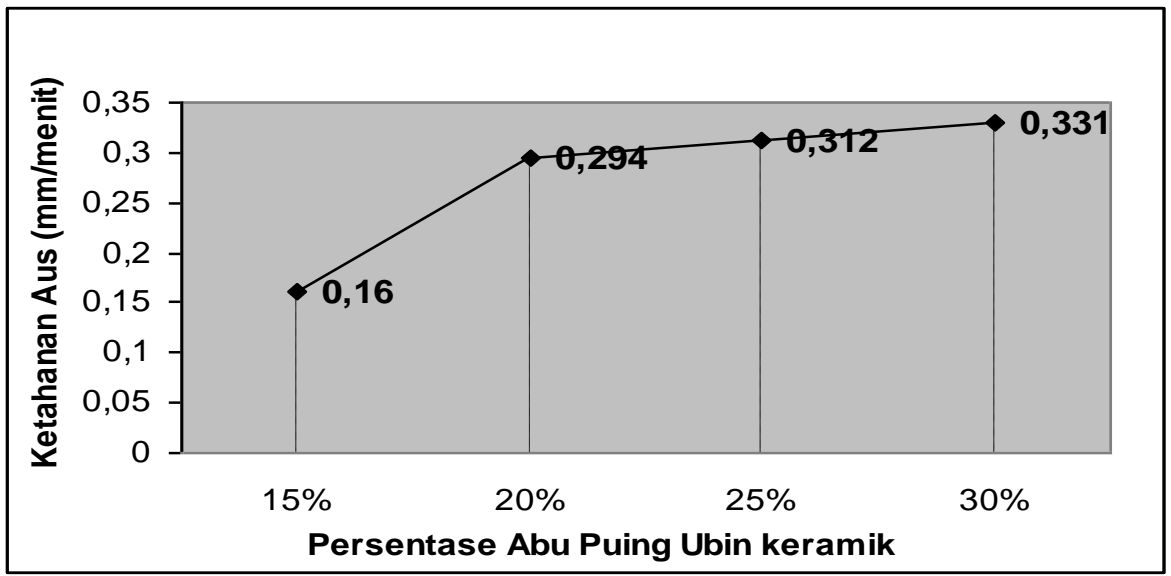

6. Pengujian Hipotesis Kuat Tekan Bata Beton

Rangkuman hasil Uji t terhadap mutu paving block yang menggunakan abu puing keramik sebagai bahan pengganti sebagian semen dengan nilai kuat tekan bata beton standar dapat dilihat pada tabel di bawah ini:

Tabel 7. Hasil Uji t Antara Nilai Rata-Rata Kuat Tekan Paving Block Yang Menggunakan Abu Puing Keramik Sebagai Bahan Pengganti Sebagian Semen Dengan Nilai Kuat Tekan Bata Beton SNI 03-06911996

\begin{tabular}{|c|c|c|c|c|c|c|c|}
\hline Kelompok & $\begin{array}{l}\text { Nilai Rata- } \\
\text { Rata Kuat } \\
\text { Tekan Paving } \\
\text { Block (Mpa) }\end{array}$ & $\begin{array}{l}\text { Standar SNI } \\
\text { (Mpa) }\end{array}$ & Hipotesis & $\mathrm{S}$ & $\mathrm{n}$ & $\mathrm{t}$ hitung & $\mathrm{t}_{\text {tabel }}$ \\
\hline $\mathrm{A}_{1}$ & 23,336 & Mutu B (20) $)$ & $\begin{array}{l}\mathrm{H}_{0}: \mathrm{A}_{1}=20 \mathrm{MPa} \\
\mathrm{H}_{0}: \mathrm{A}_{1}>20 \mathrm{Mpa}\end{array}$ & 24,97 & 10 & 3,63 & 2,82 \\
$\mathrm{~A}_{2}$ & 17.439 & Mutu C (15) & & 11,13 & 10 & 5,94 & 2,82 \\
$\mathrm{~A}_{3}$ & 16,934 & Mutu C (15) & $\mathrm{H}_{0}: \mathrm{A}_{1}=15 \mathrm{MPa}$ & 10,45 & 10 & 4,83 & 2,82 \\
$\mathrm{~A}_{4}$ & 15,526 & Mutu C (15) & $\mathrm{H}_{0}: \mathrm{A}_{1}>15 \mathrm{MPa}$ & 11,83 & 10 & 0,57 & $\begin{array}{c}\mathrm{t}_{(1-1 / 2 \alpha)} \\
=3,25\end{array}$ \\
\hline
\end{tabular}

MENARA, JURNAL TEKNIK SIPIL VOL. I, NO. 2 JULI 2006: 200-212 
Tabel 8. Hasil Uji t Antara Nilai Rata-Rata Penyerapan Air Paving Block Yang Menggunakan Abu Puing Keramik Sebagai Bahan Pengganti Sebagian Semen Dengan Nilai Penyerapan Air Bata Beton Mutu D SNI 03-0691-1996

\begin{tabular}{|c|c|c|c|c|c|c|c|}
\hline Kelompok & $\begin{array}{c}\text { Nilai Rata-Rata } \\
\text { Penyerapan Air } \\
\text { Paving Block (\%) }\end{array}$ & $\begin{array}{c}\text { Standar } \\
\text { SNI (\%) }\end{array}$ & Hipotesis & $\mathrm{S}$ & $\mathrm{n}$ & $\mathrm{t}_{\text {hitung }}$ & $\mathrm{t}_{\text {tabel }}$ \\
\hline $\mathrm{A}_{1}$ & 13,9 & 10 & & 60,419 & 4 & 60,419 & 4,54 \\
$\mathrm{~A}_{2}$ & 15,0 & 10 & $\mathrm{H}_{0}: \mathrm{A}_{1}=10 \%$ & 14,142 & 4 & 14,142 & 4,54 \\
$\mathrm{~A}_{3}$ & 15,5 & 10 & $\mathrm{H}_{0}: \mathrm{A}_{1}>10 \%$ & 7,760 & 4 & 7,760 & 4,54 \\
$\mathrm{~A}_{4}$ & 16,3 & 10 & & 56,824 & 4 & 56,824 & 4,54 \\
\hline
\end{tabular}

Tabel 9. Hasil Uji t Antara Nilai Rata-Rata Ketahanan Aus Paving Block Yang Menggunakan Abu Puing Keramik Sebagai Bahan Pengganti Sebagian Semen Dengan Nilai Ketahanan Aus Bata Beton Mutu D SNI 03-0691-1996

\begin{tabular}{|c|c|c|c|c|c|c|c|}
\hline Kelompok & $\begin{array}{c}\text { Nilai Rata- } \\
\text { Rata } \\
\text { Ketahanan } \\
\text { Aus Paving } \\
\text { Block } \\
\text { (mm/menit) }\end{array}$ & $\begin{array}{c}\text { Standar SNI } \\
\text { (mm/menit) }\end{array}$ & Hipotesis & $\mathrm{n}$ & $\mathrm{S}$ & $\mathrm{t}_{\text {hitung }}$ & $\mathrm{t}_{\text {tabel }}$ \\
\hline $\mathrm{A}_{1}$ & 0,160 & 0,219 & & & & \\
$\mathrm{~A}_{2}$ & 0,294 & 0,219 & $\mathrm{H}_{0}: \mathrm{A}_{1}=0,219$ & 4 & $-6,463$ & $-6,463$ & 4,54 \\
$\mathrm{~A}_{3}$ & 0,312 & 0,219 & $\mathrm{H}_{0}: \mathrm{A}_{1}>0,219$ & 4 & 17,924 & 4,924 & 4,54 \\
$\mathrm{~A}_{4}$ & 0,331 & 0,219 & & 4 & 16,027 & 17,220 & 4,54 \\
$\mathrm{~N}$ & & & & & & \\
\hline
\end{tabular}

\section{Pembahasan Hasil Penelitian}

Berdasarkan hasil pengujian kuat tekan, terjadi penurunan nilai kuat tekan seiring dengan bertambahnya persentase penggunaan abu puing ubin keramik. Dari hasil pengujian hipotesis dengan uji t (table 7) diketahui bahwa $t_{\text {hitung }}>t_{\text {tabel }}$ dengan taraf nyata $(\alpha)=0,01$, maka Ho ditolak yang berarti bahwa penggunaan abu puing keramik sebesar $15 \%$ dari berat semen menghasilkan nilai kuat tekan rata-rata 23,336 $\mathrm{MPa}$, lebih tinggi dari kuat tekan bata beton mutu B standar SNI 03-0691-1996 (20 MPa), sedangkan penggunaan abu puing keramik sebesar $20 \%$ dan $25 \%$ menghasilkan kuat tekan di atas kuat tekan mutu C standar SNI (15 MPa) dan penggunaan abu puing keramik sebesar $30 \%$ dari berat semen masih termasuk dalam kuat tekan standar mutu C SNI.

Semakin banyak persentase penggunaan abu puing keramik daya serap air semakin tinggi, Hasil uji $\mathrm{t}$ pada table 8 menunjukkan nilai rata-rata

Studi Mutu Bata Beton (Paving Block) Yang Menggunakan Abu Puing Ubin Keramik Sebagai Bahan Pengganti Sebagian Semen (Ir.Erna Septiandini, MT., Dosen Jurusan Teknik Sipil FT- UNJ.) 
penyerapan air $t_{\text {hitung }}>t_{\text {tabel }}$ dengan taraf nyata $(\alpha)=0,01$ yang berarti nilai ratarata penyerapan air lebih tinggi (belum memenuhi persyaratan) dari standar SNI 03-0691-1996 mutu $D(10 \%)$.

Nilai rata-rata ketahanan aus paving block semakin tinggi jika persentase penggunaan abu puing keramik semakin besar. Hanya penggunaan sebesar $15 \%$ dari berat semen yang nilai rata-rata ketahanan ausnya lebih rendah dari nilai rata-rata ketahanan aus standar SNI mutu D $(0,219 \mathrm{~mm} / \mathrm{menit})$ seperti yang ditunjukkan dengan hasil uji t pada table 9 ( $\mathrm{t}$ hitung $<\mathrm{t}$ tabel).

\section{Kesimpulan.}

Penggunaan abu puing keramik sebanyak 15\%,20\%,25\% dan 30\% dari berat semen pada pembuatan bata beton paving block yang mengunakan perbandingan campuran 1 (semen+abu puing keramik) : 4 pasir menghasilkan nilai rata-rata kuat tekan yang disyaratkan SNI 03-0691-1996. Penggunaan abu puing keramik sebanyak 15\% memenuhi persyaratan SNI 03-0691-1996 untuk mutu $B$ dan penggunaan abu puing keramik sebanyak $20 \%, 25 \%$ dan 30\% memenuhi persyaratan SNI 03-0691-1996 untuk mutu C. Sedangkan nilai rata-rata daya serap air dan nilai rata-rata ketahanan aus tidak memenuhi persyaratan SNI 03-0691-1996.

\section{Daftar Pustaka}

Balai Penelitian Bahan Dinas Perindustrian DKI Jakarta, Petunjuk Teknis Proses Pembuatan Bata Beton, Jakarta: Balai Penelitian Bahan

Departemen Pekerjaan Umum, Direktorat Jendral Cipta Karya, Direktorat Penyelidikan Masalah Bangunan, Persyaratan Umum Bahan Bangunan di Indonesia 1982, Jakarta: Yayasan LPMB, 1985

SK SNI 03-0691-1996. Bata Beton (Paving Block), Jakarta: DSN, 1996

SNI 03-1968-1990, Metode Pengujian Tentang Analisa Saringan Agregat Halus dan Kasar, Jakarta:Departemen Pekerjaan Umum,1990 
SNI 03-1750-1990, Mutu Dan Cara Uji Agregat Beton, Jakarta: Departemen Perindustrian, 1990

SNI 03-1754-1990, Cara Penentuan Kadar Butir Halus Lebih Kecil dari 50 Mikron untuk Agregat Halus Aduk dan Beton, Jakarta: DSN, 1990

SNI 03-1756-1990, Cara Penentuan Kekerasan Pasir untuk Aduk dan Beton, Jakarta: DSN, 1990

SNI 03-1970-1990, Metode Pengujian Berat Jenis dan Penyerapan Air Agregat Halus, Jakarta: Departemen Pekerjaan Umum, 1990

SNI 03-2816-1992, Metode Pengujian Kotoran Organik dalam Pasir Untuk Campuran Mortar atau Beton, Jakarta: Departemen Pekerjaan Umum, 1992

Sofiah Ariana, Studi Kuat Tekan Bata Beton (Paving Block) Dengan Abu Puing Ubin Keramik Sebagai Bahan Pengganti Sebagian Semen, Jakarta: UNJ 2003

Suhasdani, Agus dan Syarif Fadilah, Pengolahan Limbah Di PT.Mulia Keramik Indah Raya, Jakarta: Universitas Jayabaya, 2002. 